\section{AZ UKRÁN BIZTOSÍTÁSI JOGI SZABÁLYOZÁS ÉS BIZTOSÍTÁSI PIAC FŐBB JELLEMZÖI}

Dr. Buletsa Sibilla (jogász, Ungvári Egyetem Jogtudományi Kar, Polgári Jogi és Polgári Eljárásjogi Tanszék vezetöje) Panyina Júlia PhD (Ungvári Egyetem Jogtudományi Kar, Polgári Jogiés Polgári Eljárásjogi Tanszék tanára) - Chepis Olesya PhD (Ungvári Egyetem Jogtudományi Kar, Polgári Jogiés Polgári Eljárásjogi Tanszék docense) - Revutska Irina (Ungvári Egyetem Jogtudományi Kar, Polgári Jogi és Polgári Eljárásjogi Tanszék tanára)

\section{ÖSSZEFOGLALÓ}

A biztosítás a társadalom gazdasági és jogi kapcsolatainak fontos eleme. A biztosítási piac állapota tükrözi az ország gazdasági helyzetét, mivel a biztosítási kapcsolatok a nemzetgazdaság valamennyi ágát és a magánjogviszonyokat érintik, valamint tükrözik a népesség és az egyéni gazdasági egységek fizetőképességét. Az ukrán biztosítási piac ugyanakkor még mindig kialakulóban van, még nem elég hatékony, és nem nyújt teljes körűen biztonságos megoldást a nemkívánatos események megelőzésére. A biztosítási piac és annak hatékonysága a piacgazdaság szerves részét képezi. Mivel Ukrajna csak a közelmúltban kezdte meg a fejlődést a piacgazdaság útján, a biztosítási piacra is igaz, hogy kialakulóban van, és távolról sem tökéletes.

Jelen cikk elemzi az ukrán biztosítási piacot, különösen a biztosítási piac fejlődésének történetét és az utóbbi években megfigyelhető fö tendenciákat. Az írás kitér a biztosítás és a biztosítási jog fogalmainak különböző megközelítéseire is, megvizsgálja továbbá az ukrán biztosítási piac normatív-jogi és állami szabályozásának alapjait. A cikk ismerteti továbbá a viszontbiztosítási szerződés legfontosabb jellemzőit, és felvázolja az általános feladatokat, amelyek megoldása szintén szükséges a modern ukrán biztosítási piac helyzetének javításához.

\section{SUMMARY}

Insurance is an important element of both economic and legal social relations. The state of the insurance market reflects the economic situation in the country, because the insurance relations affect all sectors of the national economy, the private sector, and also reflects the level of solvency of the population and individual economic entities. However, the insurance market in Ukraine is still in the process of formation and is still not a sufficiently effective and full-fledged security tool to prevent adverse events. The insurance market and its efficiency are an integral part of a market economy. As Ukraine has recently started to market economic development, the insurance market is still in its infancy and doesn't function perfect.

This scientific article is devoted to the research of the Ukrainian insurance market, in particular the history of the development of the insurance market in independent Ukraine and the main tendencies observed in this market in recent years. Different approaches to the concept of insurance and insurance law are analyzed. This paper focused on bases of normative-legal and state regulation of the insurance market of Ukraine. The key features of the reinsurance contract are presented and the general tasks to be necessary to improve the situation in the modern insurance market of Ukraine are listed.

Kulcsszavak: biztosítás, biztosítási piac, biztosító, biztosított, állami szabályozás Keywords: insurance, insurance market, insurer, insured, state regulation

\section{JEL: G22, K15}

DOI: $10.18530 /$ BK.2018.1.90

http://dx.doi.org/1018530/BK.2018.1.90

\section{Bevezetés}

Az ukrán biztosítási piac működésének és fejlődésének problémáit olyan kutatók tanulmányozták, mint V. Bazylevych, N. Vnukova, S. Osadets, N. Tkachenko, V. Furman. Az ukrán biztosítási piac európai integrációjának jelenlegi helyzetét és kilátásait pedig D. Dem, O. Vilenchuk, V. Gryshchenko, I. Demyanyuk, A. Filonyuk és A. Shoihedenko vizsgálták munkáikban.

A biztosítási kapcsolatok lényegére és tartalmára koncentráltak tanulmányaikban V. P. Janishen, O. V. Grinyuk, N. B. Patsuria, B. C. Belich, I. V. Krivosheyev, V. Yu. Abramov, V. M. Nikiforak és sok más tudós. A polgári felelösségbiztosítás kérdését pedig külföldi és ukrán kutatók elemezték, úgymint P. Golub, N. Kopylkova, O. Krasilnikova, K. Maslova, L. Melnikova, O. Posoch, T. Rosolova, O. Fayer és mások.

Az ukrán biztosítási piac számos problémával és kihívással néz szembe, melyek érintik mind a biztosítási kapcsolatok jogi szabályozását, mind a biztosítási piac szereplőinek tevékenységét. Ukrajnában folyamatosan csökken a biztosítótársaságok száma, ami mutatja egyes biztosítók elégtelen pénzügyi működését. Az ukrán társadalomban a biztosítási kultúra hiánya is problémaként jelentkezik, ami részben a lakosság alacsony fizetőképességének a következménye. Mindezek a tényezők összességében megnehezítik a biztosítási piac működését, mely egyelőre távol áll az európai biztosítási normáktól.

Jelen cikk célja, hogy átfogó elemzést nyújtson a biztosítási kapcsolatok jogi szabályozásának legfontosabb jellemzőiről Ukrajnában, valamint elemezze az alapvető jogszabályokat és problémákat a biztosítási piac kialakulása szempontjából. 


\section{Az ukrán biztosítási piac kialakulásának és fejlődésének története}

A biztosítás fogalma latin eredetű. Olyan szavakon alapul, amelyek „gondtalanságot” jelentenek. Ennek következtében a biztosítás tükrözi a figyelmeztetés, a védelem és a biztonság fogalmait. Ugyanakkor sok szláv nyelvben, beleértve az ukrán nyelvet is, a biztosítás fogalmának kialakulása összefügg a „félelem” szóval (Kremena, M. L., 2014, 262).

A biztosítás jogi és gazdasági tartalommal bír. A jogi tartalom egyfajta polgári jogviszonyt fejez ki, mely szerint a magánszemélyek és jogalanyok vagyoni érdekeik védelme érdekében megkötött biztosítási szerződés alapján az abban foglaltaknak megfelelően vagy a hatályos jogszabály által meghatározott események bekövetkeztekor (biztosítási esetek) a biztosító térítést nyúit azon pénzalapokból, melyek forrása az egyének és a jogi személyek által befizetett biztosítási díjak, illetve az ezen pénzeszközök kihelyezéséből származó jövedelem (85/96-VR Sz. „A biztosításról” szóló törvény, 1996).

Gazdasági tartalom: A gazdasági kapcsolatok azon rendszere, amely meghatározott szereplők között alakul ki, ezek a szereplők a biztosítók és a biztosítottak. A biztosítás működésének egyik fontos előfeltétele az üzleti vállalkozások tulajdonosi függetlensége, valamint azon érdek, hogy a vállalkozás a kockázatot egy, a kockázatok kezelésére szakosodott intézménynek adja át. Minél nagyobb ez az érdek, annál magasabb a biztosítás iránti igény (Kremena, M. L., 2014, 262)

Az ukrán biztosítási piac kialakulásának történelmi szempontjait figyelembe véve meg kell jegyezni, hogy a Szovjetuniónak nem volt olyan alapjoga, mely szabályozta volna a biztosítási tevékenység művelését. Mivel a biztosítási tevékenységeket kizárólag az állami és a bennfentes biztosítási intézetek végezték, amelyek nem rendelkeztek független státusszal, nem volt szükség olyan jogalkotási normák megfogalmazására, amelyek jogszabályi szinten rögzítenék a jogalanyok jogait és kötelezettségeit. A biztosítási tevékenység bizonyos kérdéseit a Szovjet Szocialista Központi Bizottság és a Szovjetunió Miniszterek Tanácsa, valamint az Ukrán SSR, az állami biztosítási és Ukrderzhstrakh jogi dokumentumai szabályozták (Szobol, R.G., 2008).

Ukrajna biztosítási piaca azt követően kezdett el fejlődni, hogy az ország független, demokratikus állam lett, amelyben megjelent a piacgazdaság.

A biztosítási piac a piacgazdasági infrastruktúra szükséges és fontos eleme, mely szorosan kapcsolódik a termeléshez, a fogyasztáshoz, a munkaerőpiachoz, a tőkepiacokhoz és az értékpapírokhoz. A fejlett piacgazdaságokban a biztosítás széles körben elterjedt, fedezetet nyújt a gazdasági élet szereplőinek a különböző típusú kockázatokra, mint például balesetek, pénzügyi kockázatok, bűncselekmények, természeti és egyéb katasztrófák (Szobol, R.G., 2008).

Ukrajna függetlenségének megszerzésétől egészen mostanáig az ukrán biztosítási piac fejlödése három fö szakaszra osztható fel:

I. szakasz (1991-1995.) - Ebben az időszakban fogadták el az első biztosítási jogszabályokat. Különösen fontos volt „A bankokról és banki tevékenységről szóló törvény módosításáról és kiegészítéséről” szóló Ukrán Minisztertanácsi Rendelet, mely 1993-ban lépett hatályba. Ez a rendelet megtiltotta a kereskedelmi bankok tevékenységét a biztosítási szektorban, ami hozzájárult a biztosítótársaságok müködésének fejlődéséhez (A 38-93. sz. Ukrán Minisztertanácsi Rendelet, 1993). Ezen túlmenően 1993-ban megalapításra került az ukrán biztosítási piacot szabályozó államszervezet, az „Ukrstrahnahlyad”. Mindezek ellenére az ukrán biztosítási piac csak mennyiségi, és nem minőségi értelemben növekedett, mivel hiányzott a piac fejlődéséhez szükséges módszertani alap, szakképzett munkaerő, továbbá a szükséges biztosítói tőke (Kremena, M. L., 2014, 263);

II. szakasz (1996-2002.) - 1996-ban a „Biztosításról” szóló ukrán törvény elfogadásával kezdődött, amely új fejezetet nyitott az ukrán biztosítási piac történetében. Ez átmeneti időszak volt a tervgazdaságtól a piacgazdaság irányába, amely a szabályozási keretek aktualizálásával járt. E tekintetben a „Biztosításról” szóló törvényen kívül 1996 és 2002 között 20 kormányhatározat, 11 utasítás és egyéb normatív jogi aktus került elfogadásra. Ezek a jogi aktusok közvetlenül meghatározták az alkalmazandó biztosítási szabályokat azon a területen, ahol a nem állami tulajdonú biztosítótársaságok meghatározó szerepet játszottak. Megemelték továbbá a biztosító alapításához szükséges minimális tőkekövetelményt 5 ezer dollárról 100 ezer dollárra, aminek következtében jelentősen csökkent a biztosítók száma. (1997-ben Ukrajnában csak 220 biztosítótársaság volt.)

III. szakasz (2002-től a mai napig) - Ez egy új minőségű időszak a piac fejlődésében. 2001 végén hatályba lépett a „Biztosításról” szóló ukrán törvény új változata, amely új tőkekövetelményeket állapított meg a biztosítók számára: legalább 1 millió euró azok számára, akik kockázati biztosítással foglalkoznak, illetve legalább 1,5 millió euró életbiztosítással foglalkozó biztosítók esetében. 2005-ben ez a törvényi rendelkezés ismét megváltozott, így jelenleg az életbiztosító minimálisan elvárt tőkeszükséglete 10 millió eurónak megfelelő érték az ukrán nemzeti valuta devizaárfolyamán számítva (85/96-VR Sz. „A biztosításról” szóló törvény, 1996). Az ilyen változások fontos szerepet játszottak az ukrán biztosítótársaságok fizetőképességének és versenyképességének erősítésében, hogy képesek legyenek a várható fizetési kötelezettségeiket időben teljesíteni.

Ezen túlmenően a harmadik fázis a biztosítási piac szabályozását új szabványokra és megközelítésekre alapozta. Jelentősen megnövekedett a verseny és a szakmaiság szerepe a biztosítók munkájában. 2002 végén megalakult a Pénzügyi Szolgáltatási Piacok Szabályozásával Foglalkozó Állami Bizottság, a piaci kapitalizációra vonatkozó követelmények szigorúbbá váltak. Létrejött a biztosítási tevékenységek állami felügyelete. Ezen felügyelet feladata az ukrán biztosítási jogszabályok végrehajtatása, a biztosítási szolgáltatások hatékony fejlesztése, a biztositók fizetésképtelenségének megakadályozása és a kötvénytulajdonosok érdekeinek védelme. A biztosítási tevékenység állami felügyeletét Ukrajna területén az Ukrán Pénzügyminisztérium és helyi hatóságai végzik (Kremena, M. L., 2014, 263).

Valószínűleg kedvezően befolyásolta a biztosítási piac fejlődését a körülbelül két tucat új kötelező biztosítási típus bevezetése. Ilyen típusú kötelező biztosítások közé tartoznak például a befektető polgári felelősségbiztosítása, az exportőr felelősségbiztosítása, a tengeri fuvarozói biztosítás, a vízi közlekedés, a nukleáris létesítmények személyzete, az űrtevékenység tárgyai, mint a földi infrastruktúra, légi járművek, áramvezetékek, magán közjegyző polgári felelősségbiztosítás és továbbiak (Hetmanets, O.P. - Shumilo, O. M. - Kolesnik, T. V., 2014, pp. 48-49). 


\section{Az ukrán biztosítási piac jelenlegi változása}

A biztosítótársaságok száma Ukrajnában 2017. március 31-én elérte a 307-et, melyből 39 biztosító „életbiztosító” volt, 268 pedig „nem-életbiztosító”. (2016. március 31-én a vállalatok száma összesen 352 volt, ebből „életbiztosító” 46, „nem-életbiztosító ” pedig 306.) A biztosítótársaságok száma folyamatosan csökken: 2017-ben a 2016-os évhez képest a biztosítók száma 45-tel csökkent. Összehasonlítva 2016 első negyedévével 2017-ben a bruttó biztosítási díjak nőttek 2622,0 millió hrivnyával (31,7\%), és a nettó biztosítási díjak is emelkedtek 176,3 millió hrivnyával (2,8\%). Megállapítható, hogy a biztosítási piacon működő jelentős számú társaság ellenére a bruttó biztosítási díjak 98,3\%-át 100 „nem-életbiztosító” biztosító jegyzi (ami az összes nem életbiztosító 37,3\%-át jelenti), az életbiztosítók esetében pedig a díjbevétel 99,8\%-át 20 „életbiztosító” biztosító állítja elő (ami az életbiztosítók 51,3\%-át jelenti). Az életbiztosítási piacon 2017-ben a Herfindahl-Hirshman (HHI) mutatója 1328,92 volt (2016 első negyedévében 974,53), a kockázatbiztosítási típusok piacán pedig 431,35 volt (2016 első negyedévében ez az érték 344,70 volt). 2017-ben az összesített biztosítási piac Herfindahl-Hirshman mutatója 387,19 volt (2016 első negyedévében ez az érték 298,04 volt) (Forinsurer, 2017).

A Herfindahl-Hirshman index az üzleti tevékenység koncentrációját tükrözi egy adott piacon. Bár az Amerikai Igazságügyi Minisztérium piaci koncentrációjának meghatározására alkalmazott módszer szerint az 1000-nél kisebb index a piac enyhe koncentrációját tükrözi, az index emelésének tendenciája ugyanakkor azt jelzi, hogy a piaci koncentráció növekszik, következésképpen a verseny csökken, ami nem szolgálja az ügyfelek érdekét (Wikipedia, 2016). A Herfindahl-Hirshman index egy naptári évben bekövetkezett jelentős növekedése így azt mutatja, hogy az ukrán biztosítási piacon kedvezötlen folyamatok vannak jelen.

Az ukrán biztosítási piacon tapasztalt negatív változások túlnyomó többsége az ukrán társadalom szociális, gazdasági és politikai változásai miatt következett be.

2017 első negyedévében a következő változások voltak tapasztalhatóak a magánszemélyekkel kötött biztosítási szerződések esetében:

- a közlekedési balesetekre kötött biztosítási szerződések száma 8923700 darabbal csökkent 2016 első negyedévének megfelelő mutatójához képest;

- a megkötött balesetbiztosítási szerződések száma 6262600 darabbal nőtt 2016 első negyedévének megfelelő mutatójához képest;

a pénzügyi kockázatokra kötött biztosítási szerződések száma 2437000 darabbal nőtt 2016 első negyedévének megfelelő mutatójához képest;

- az egészségbiztosítási megkötött szerződések száma 1266600 darabbal nőtt a 2016-os év első negyedévének megfelelő mutatójához képest;
- az ingatlanbiztosítási szerződések száma 201100 darabbal nőtt 2016 első negyedévének megfelelő mutatójához képest;

- a tűzveszély és a természeti katasztrófák esetére megkötött biztosítási szerződések száma 61800 darabbal csökkent 2016 első negyedévének megfelelő mutatójához képest;

- a megkötött életbiztosítási szerződések száma 164200 darabbal csökkent 2016 első negyedévének megfelelő mutatójához képest (Forinsurer, 2017).

Hasonló helyzet volt megfigyelhető a piacon a korábbi években is. Különösen 2015ben, amikor a biztosítók teljes eszközállománya csökkent 4111,3 millió hrivnyával, ami a biztosítótársaságok számának csökkenéséből és a biztosítók mérlegéből származó illikvid eszközök leírásából adódott. Ugyanakkor a biztosítótársaságok számának csökkenése ellenére 2010-hez képest a bruttó díjbevételek 28,8\%-kal nőttek, míg a kifizetések növekedése $32,7 \%$ volt. A biztosítási díjak növekedésének fö forrása a rakomány- és poggyászbiztosítás $(93,0 \%)$, valamint az autóbiztosítás $(20,0 \%)$ voltak (Szukach, O. M. - Saran, L. A., 2016, 109).

Az ukrán biztosítási piacon tapasztalt negatív változások túlnyomó többsége az ukrán társadalom szociális, gazdasági és politikai változásai miatt következett be. A helyzet általános romlására vonatkozó okok és előfeltételek részletesebb magyarázata érdekében mélyebben meg kell vizsgálni a biztosítási jogviszonyokra vonatkozó normatív-jogi és különösen az állami szabályozást, valamint bizonyos típusú biztosítási szerződések jellemzőit.

\section{A biztosítás jogi szabályozása Ukrajnában}

Az ukrán biztosítási piac jogi szabályozásának rendszere meglehetősen elágazó, számos központi és helyi jogszabályt tartalmaz, mely szabályok két külön blokkra bonthatóak. Az első olyan törvényblokk, amely a gazdasági tevékenységet szabályozza. Ez általános jog, mely minden gazdasági egységre vonatkozik, mégpedig a következők:

1) az Ukrán Alkotmány rendelkezései a vagyonról, a vállalkozásról, a legmagasabb államhatalom hatásköréről a gazdasági tevékenység normatív szabályozásában stb.;

2) kodifikált jogi aktusok: Ukrajna Polgári Törvénykönyve, Ukrajna Kereskedelmi Törvénykönyve, Ukrajna Vámkódexe, Ukrajna Légi Kódexe stb.;

3) olyan törvények, melyeket általánosnak lehet minősíteni. Ezen törvényblokk célja minden gazdasági egység tevékenységének szabályozása, függetlenül attól, hogy szakosodtak-e valamilyen tevékenységre („A jogi személyek nyilvántartásáról, az egyéni vállalkozókról és a közintézményekről”, „A gazdasági társaságokról”, „A részvénytársaságokról”, „Az értékpapírokról és a tözsdéröl” szóló törvények stb.). Ezek a törvények meghatározzák a jogi formákat, a részvénytársaságok alapításának eljárásait, a jogaikat és kötelezettségeiket, valamint más általános rendelkezéseket;

4) alárendelt szabályok: Ukrajna elnökének határozatai és rendeletei, az Ukrán Minisztertanács határozatai és rendeletei, minisztériumok normatív aktusai. 
A második blokk tartalmazza a biztosítási tevékenységet szabályozó különös jogszabályokat: 1) „A biztosításról” szóló törvény tartalmazza a biztosítási tevékenység szabályait, eljárásrendjét és feltételeit, illetve bizonyos típusú biztositások speciális szabályait (például törvény „A szárazföldi jármüvek tulajdonosainak kötelezö polgári jogi felelősségbiztositásáról”, „A kötelezö állami társadalombiztosításról”, „A kötelezö állami nyugdijbiztositásról” stb.);

2) az Ukrán Parlament állásfoglalásai a biztosítási tevékenységekről

3) az ukrán elnök rendeletei és az ukrán minisztertanácsi határozatok a biztosítási tevékenység kérdéseiről. Például az Ukrán Minisztertanács külön határozatai, amelyek meghatározzák a biztosítási tevékenységet végző szervezetek létrehozására, müködésére, átszervezésére és felszámolására vonatkozó eljárást. A kormányrendeletek szabályozzák az egyes kötelező biztosítási formák és állami kötelező biztosítások végrehajtásának eliárását is (körülbelül 20 kötelező biztosítástípust).

Az Ukrán Minisztertanács külön határozata a kötelező biztosítások esetében megszabja az ügyviteli költségek legmagasabb összegét, valamint szabályozza az állami és a nemzeti biztosítótársaságok és a kötelező biztosítói társulások létrehozásának folyamatát. A határozatok segítségével szabályozhatók a külön díjakra vonatkozó korlátozások, a szerződési feltételek stb., de csak abban az esetben, ha ez nem ellentétes Ukrajna törvényeivel (Szobol, R.G., 2008);

4) az illetékes hatóságok biztosítási tevékenységet szabályozó rendeletei és határozatai (elsősorban a Nemzeti Pénzügyi Szolgáltatások Bizottsága);

5) helyi szabályozás (például a biztositási szabályok, amelyek alapján különálló biztosítótársaságnál köthetők a biztosítási szerződések). Ebben az esetben a helyi szabályozás hatása csak arra a biztosítótársaságra terjed ki, amelynek hatáskörében a helyi szabályozás elfogadásra került (Hetmanets, O.P. - Shumilo, O. M. - Kolesnik, T. V., 2014, pp. 44-45).

Napjainkban megfigyelhetjük azt a tendenciát, hogy a biztosítók nagyszámú helyi dokumentumot hoznak létre. Ez a gazdasági liberalizáció, az üzleti vállalkozások gazdasági függetlenségének kiterjesztése és más objektív és szubjektív okok miatt következik be. Így a helyi dokumentumok meghatározzák a biztosítók egyéni jogállását, az önkéntes biztosításra vonatkozó szabályokat és feltételeket, amelyeket a biztosítótársaságok saját maguk fejlesztenek és fogadnak el, és azok nem mondhatnak ellent a hatályos jogszabályoknak (Hetmanets, O.P. - Shumilo, O. M. - Kolesnik, T. V., 2014, pp. 45-46).

Annak ellenére, hogy a biztosítások területén nagyszámú szabályozási aktus van, amit nehéz pozitív jelenségként értékelni, az ukrán biztosítási jogszabályok még mindig hiányosak, nem tökéletesek, mivel nem teljes mértékben felelnek meg a biztosítási piac tényleges szükségleteinek.

A jogi szabályozás kiterjedt rendszere és a biztosítási kapcsolatok sajátosságai - egyes tudósok szerint - különálló biztosítási jog létezését igazolják. Nehéz azonban egyetérteni ezzel a gondolattal. A biztosítási jogviszony magában foglalja a vagyoni viszonyokat, a biztosítási tevékenység megszervezéséhez füződő kapcsolatokat, a pénzügyi intézményekkel, a költségvetéssel, azállami hatóságokkal és az igazgatással, valamint a más jogalanyokkal szabályozott kapcsolatokat. Tehát ennek alapján azt lehet mondani, hogy a biztosítási kapcsolatokra irányuló szabályok bonyolultak, és elkülönülnek egy magán jogintézményben. A biztosítási kapcsolatokra vonatkozó jogi normák teljes egésze azonban nem rendelkezik a függetlenség objektív tulajdonságaival, amelyek minden egyes jogterületen jellemzőek. Ezért helyesebb lenne egy átfogó biztosítói jogrendszer létezéséről beszélni a polgári jogrendszerben (Koszinszkaya, V. A., 2013, 215). A biztosítás azonban nem külön jogi ágazat, sőt, még csak nem is alágazat.

A biztositási piac stabil és hatékony működése érdekében a biztosítási tevékenység Ukrajnában állami szabályozásnak van alávetve, és kötelező engedélyezést igényel.

A biztosítási tevékenység és a biztosítási piac általános szabályozását a következő kormányzati szervek végzik:

- Az Ukrán Parlament és Ukrajna Minisztertanácsa - megalkotják a biztosítási tevékenység állami szabályozásának jogalapját, és biztosítják ezeknek a jogszabályoknak a végrehajtatását;

- Nemzeti Pénzügyi Szolgáltatások Bizottsága - a biztosítási tevékenység állami szabályozásának közvetlen központi szervezete;

- Ukrán Nemzeti Bank - a nemzeti valuta szabályozásával kapcsolatos feladatokat végzi;

- Állami Adóhatóságok - adószabályozással kappcsolatos feladatok ellátása;

- Monopóliumellenes Bizottság - feladata a dömpingellenes és monopóliumellenes politika;

- Állami Szabályozó Szolgálat - szabályozási politika fejlesztése és végrehajtatása;

- Nemzeti Értékpapír-és Pénzpiaci Bizottság - feladatköre a részvénytársaságok tevékenysége;

- Gazdasági Bíróság - a biztosítási jogvitákkal kapcsolatos ügyekkel foglalkozik (Hetmanets, O.P. - Shumilo, O. M. - Kolesnik, T. V., 2014, pp. 51-52).

A biztosítási tevékenység állami szabályozásának struktúrája három részre osztható: előzetes felügyelet, folyamatos felügyelet és szükséghelyzetben végzett felügyelet:

1) előzetes felügyelet - engedélyezési eljárás, vagyis egy biztositó piaci tevékenységének elkezdését érinti;

2) folyamatos felügyelet - biztosítja a biztosító aktuális tevékenységének ellenőrzését, ami magában foglalja a:

- biztosítók fizetőképességének a felügyeletét:

befektetési tevékenységük felügyeletét;

- a vállalatirányítás felügyeletét.

3) szükséghelyzetben végzett felügyelet - célja, hogy a biztosító irányítása az engedély visszavonása vagy egy felszámolási eljárás megindítása után is biztosított legyen (Ziskind, I. O., 2009, 38.).

A biztosítási tevékenység megkezdésére vonatkozó engedélyt az Ukraina Nemzeti Pénzügyi Szolgáltatások Bizottsága adja ki. Miután a biztosító benyúitotta a jogszabályokban meghatározott iratokat, az Ukrajna Nemzeti Pénzügyi Szolgáltatások Bizottságának valamennyi alkörzete tanulmányozza a benyújtott dokumentumokat, és szükség esetén megjegyzést füz hozzájuk. A biztosítók ezekkel a megjegyzésekkel összhangban kötelesek pótolni a hiányosságokat, különös tekintettel azon feltételek teljesítésére, melyek az engedélyezni kért terméktípushoz kapcsolódnak. Ugyanakkor Ukrajna Nemzeti Pénzügyi Szolgáltatások Bizottsága arra összpontosít, hogy a szabályok megfeleljenek a törvény követelményeinek, valamint hogy bizonyos rendelkezések ne 
vezethessenek a kötvénytulajdonosokkal szembeni visszaélésekhez. Ezenkívül figyelemmel kíséri, illetve ellenőrzi a biztosítási díjak számítását, különösen azt, hogy az megfelel-e a biztosításmatematika és statisztika világszerte alkalmazott rendszerének (Medvid, Y.F., 2013, pp. 149-152).

Fontos kiemelni, hogy „A biztosításról” szóló törvény értelmében a biztosítók csak olyan biztosítási terméket értékesíthetnek, melyre előzetesen engedélyt kaptak (85/96-VR Sz. „A biztosításról” szóló törvény, 1996)

A fentieket összegezve elmondható, hogy Ukrajnában a biztosítási tevékenység állami szabályozása meglehetősen kiterjedt és kellően fejlett.

Az ukrán biztosítási piac résztvevőihez a következők tartoznak: 1) a biztosítást végző biztositók; 2) biztosítási közvetítők (ügynökök), viszontbiztosítók, kölcsönös biztosítótársaságok;3) biztosítási szolgáltatások vásárlói (biztosítottak - jogi és egyéni személyek); 4) kockázat- és veszteségbecslők (biztosítóintézetek, ügyvédek, orvosi rendelők, vészhelyzeti bizottságok); 5) biztosítók és biztosítottak társulásai; 6) a fent említett biztosítási ellenőrző szervek (Shirinyan, L., 2012, 136).

\section{Casco biztosítás}

Indokolt külön kitérni egy olyan széles körű, önkéntes biztosítástípusra, mint a casco gépjármü-biztosítás. A casco világszerte elterjedt, a gépjárművek számának folyamatos növekedése, illetve a veszélyes üzemi jelleg egyaránt arra ösztönzik a gépjárművek tulajdonosait, hogy kötelező elöírás nélkül is megkössék ezt a biztositást.

Mivel a nem kötelezően elöírt biztosítások megkötésének kultúrája Ukrajnában alacsony, a casco biztosítás sokszor az első biztosítási szerződés a legtöbb ukrán állampolgár életében. Ez azzal magyarázható, hogy az ukránok többségében nem hajlandóak önként biztosítani a tulajdonukat. Ugyanakkor a casco biztosítási szerződést az esetek túlnyomó többségében a fogyasztóknak a gépjármű hitelre történő vásárlásakor meg kell kötnie, mivel a hitelre értékesített autóknál a konstrukció magában foglalja a zálogjogot is, melyre a biztosítás nyújt fedezetet (Tkachenko, N.V. - Krynica, S.O., 2013, pp. 171-172.).

2009-ig az új autók értékesítése és ennek megfelelően a gépjármü-biztositási kötvények értékesítése folyamatosan nőtt Ukrajnában. Az autóhitelek számának csökkenése 2009-ben azonban kulcsfontosságú tényező volt, ami a casco szerződések értékesítésének csökkenéséhez vezetett, és egyben tovább növelte a biztositók versenyét a potenciális ügyfelekért a biztosítási piacon (Tkachenko, N.V. - Krynica, S.O., 2013, 174.)

\section{Kötelező biztosítások}

A kötelező biztosítások tekintetében az egyik legelterjedtebb biztositástípus a szárazföldi gépjárművek tulajdonosainak polgári jogi felelősségbiztosítása. A szárazföldi gépjárművek tulajdonosai polgári jogi felelősségének kötelező biztositási piacának állami szabályozását közvetlenül a Nemzeti Pénzügyi Szolgáltatások Bizottsága és az Ukrán Motor (Közlekedési) Biztosítási Hivatala végzik. Ennek az intézménynek a létrehozása „A szárazföldi gépjárművek tulajdonosainak polgári jogi felelősségének kötelező biztosításáról" szóló ukrán törvény elfogadásához kapcsolódik, amely 2005 óta van hatályban. Az Ukrán Motor (Közlekedési) Biztosítási Hivatalt azért hozták létre, hogy biztosítsa azon biztosítók fizetőképességét, a kötvénytulajdnosok felé a kötelezettségeik teljesitését, melyek törvényesen jogosultak a szárazföldi gépjárművek tulajdonosainak kötelező felelősségbiztositásának megkötésére (Bacho, R.Y., 2015, pp. 358-359.)

Az Ukrán Motor (Közlekedési) Biztositási Hivatal egyik legutóbbi intézkedése, hogy a szárazföldi gépjármüvek tulajdonosainak kötelező felelősségbiztosítása vonatkozásában bevezették az elektronikus kötvényt. Ennek köszönhetően a biztosított a biztosítási szerződést közvetítők nélkül is megkötheti az interneten keresztül vagy a biztosítótársaság irodájában nem papíralapú formában. Ezen szerződéskötési módszer előnye részben az, hogy nem szükséges előzetesen a formanyomtatványokat papíron elóállítani, ami a biztosítás költségeinek viszonylagos csökkenéséhez vezet, másrészt csökkenti a biztosítási csalások számát, illetve a visszadátumozott biztosítási kötvények kiállításának lehetőségét (Bacho, R.Y., 2015, 363.).

Az Ukrán Motor Biztosítási Hivatal létrehozása és müködtetése hozzájárult a gépjármű-tulajdonosok polgári felelősségbiztosítási szegmensének jelentős fejlődéséhez, és lehetővé tette a legjobb európai tapasztalatok átvételét, ami a következő elemeket jelenti: az europrotokoll bevezetése; a veszteségek közvetlen elszámolása; az elektronikus biztosítás bevezetése (Bacho, R.Y., 2015, 364.).

\section{Viszontbiztosítási szerződés}

A biztosítási kapcsolatok bemutatásakor szükséges megvizsgálni a viszontbiztositási vonatkozásokat is.

„A biztosításról” szóló törvény 12. cikke értelmében a viszontbiztosítás egy biztosító (viszonteladó) biztosítását jelenti egy másik rezidens vagy nem rezidens biztosítónál (viszontbiztosító), amely a szerződésben meghatározott feltételek szerint átvállalja a kockázatok/teljesítés egy részét. A viszontbiztosítási szerződések regisztrációkötelesek (85/96-VR Sz. „A biztosításról” szóló törvény, 1996.).

A kutatók között sok éve vita folyik a viszontbiztositási szerződés természetéről. Egyes tudósok úgy vélik, hogy a viszontbiztosítási szerződés egyfajta biztosítási szerződés, míg mások azzal érvelnek, hogy a viszontbiztosítási szerződés sajátosságai révén önálló polgári jogi szerződés.

Azok a tudósok, akik elismerik a viszontbiztositási szerződés függetlenségét és különlegességét a biztosítási szerződésekhez képest, az alábbi érveket sorakoztatják fel:

1) a viszontbiztosítási kötelezettségek kiegészítő jellege a biztositási szerződéshez képest;

2) a biztositási és viszontbiztositási szerződések különböző résztvevői;

3) általános szabályként a viszontbiztosítási szerződés konszenzusos, a biztosítási szerződés megkötésének szabályai ugyanakkor kötöttek;

4) a viszontbiztosítást a viszontbiztosítási szokások és a jogi gyakorlat szabályozza, míg a biztosítási szerződést a törvény szabályozza;

5) a viszontbiztosításban nincs kapcsolat a viszontbiztosító és a biztosított között a főszerződés alapján;

6) a viszontbiztosítási szerződés szinte soha nem létezik „tiszta” formájában;

7) számos egyéb eltérés van a biztositási és viszontbiztosítási tevékenység között (Vinnychuk, R.I., 2014, pp. 10-11.). 
Így a legtöbb ukrán kutató arra a következtetésre jut, hogy a viszontbiztosítási jogviszony különös jogi struktúra a biztositási üzletág területén, és a viszontbiztositási szerződés a biztosítási szerződéshez képest független típusú szerződés.

\section{Zárszó}

Összefoglalva megállapíthatjuk, hogy az ukrán biztosítási jogviszonyok szabályozása meglehetősen fejlett, bár a nagyszámú szabályozási aktus jogi értelme általában negatívumnak tekinthető. Elmondható továbbá, hogy a biztosítási piacállami szabályozása különböző gazdasági, adminisztratív és pénzügyi módszerek alkalmazásával a megfelelő szinten történik. Ugyanakkor arra is rá kell mutatni, hogy Ukrajnában negatív tendenciák tapasztalhatók a biztosítási piac fejlödésében. Az ukrán magánés jogi személyek ritkán kötnek önkéntes módon biztositási szerződést a biztosítási dijak változása miatt, aminek oka azállam általános gazdasági helyzete, illetve a társadalmi-politikai körülmények.

Az elvégzett kutatások alapján arra a következtetésre juthatunk, hogy az ukrán biztosítási piac helyzetének romlása összetett problémának tekinthető, annak megoldására pedig a következő intézkedéseket kell hozni:

az ország gazdasági helyzetének javítása, különösen a lakosság és az üzleti vállalkozások fizetőképességének növelése

a biztosítási szolgáltatások fogyasztói megfelelő védelmének biztosítása;

állami intézkedések a biztositók fizetőképességének növelésére;

a kötelező biztosítástípusok meghatározási módszereinek korszerüsítése

a biztosítási piac szervezésében, szabályozásában és felügyeletében szerzett európai tapasztalatok átvétele.

A biztositási kapcsolatokra vonatkozó jogszabályok tekintetében ugyanakkor megfelelő rendszerezésre van szükség, mivel azok számos különböző szabályozásban kerültek rögzítésre, ahogyan azt a szerzők a jelen cikkben is igyekeztek bemutatni.

\section{IRODALOMJEGYZÉK}

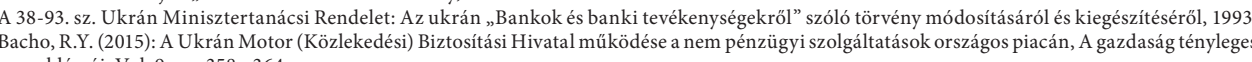

Forinsurer (2017): A
letölttve 2018.02.19.

Hetmanets, O.P. - Shumilo, O. M. - Kolesnik, T. V. (2014): A biztositásis tevékenyyég jogi szabályozása: kézikönnyv, Hi-Tech Press. Medvid, Y.F. (2013): A biztositásis tevékenység àllami szabalyozazasa és felügyeletének jellemzói Ukrajanaban, Törvényünk, Vol. 13, pp. 149-152

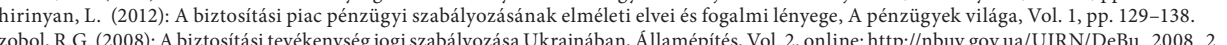
letöltve 2018.02.19.

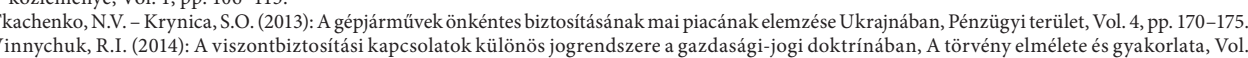

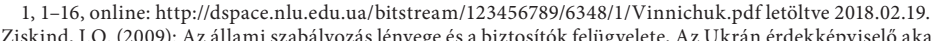

https://en.wikipedia.org/wiki/Herfindahl_index letöltve 2018.02.19.

\section{SZERZÖI ÚTMUTATÓ}

A BIZTOSÍTÁS ÉS KOCKÁZAT FOLYÓIRATBAN PUBLIKÁLÓK RÉSZÉRE

A kéziratokat elektronikus (Word-Excel-faji) formátumban mellekkletként A A kézirat befogadásához csatoloniszzükségesakitiöltött tzerzỏinnyilatkozatotis Terjedelmi ajälás: 1-1,5iv $(1$ iv $=40000$ karakkter). A közlemények hossza

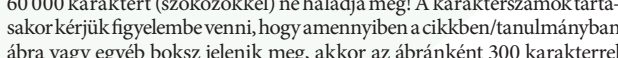
ábra vagy yegyeb boksz jelenik meg, akkor az ábránként 300 karakterrel
kerüllbeszámitasra. kerüu beszámitásr

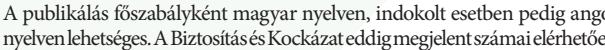

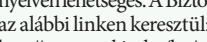

Akeziriat aövetkező elemeket tartalmazza az alabbi sorrendben:

A cikk címe, szerzője, elérhetōsége. A cikk beadásának dátuma. Több

- CIKK Címe

Alcím (opcionális)

- SZERZOPKNENEVEÉSAZAZOKAZADATOK,MELYEKET

- OUdományos fokozaz

Magyar nyelven, maximum 1000 karakter

Angol nyelven, maximum 1000 karakt

- Maximum 5

: Maxim

- EZtaMABISZadja.

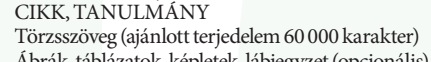

Ärák, tabliazatok, vépletetel

1. Acímoldalon sorrendben akövetkezók szerepelejenk: akéziratcíme, esetle alcíme, a szerzzők neve, a szerzzők tudományos fokozata, titulusa, a szerzỏi

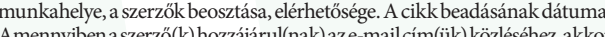
ittezt is kérü̈k megadni.

lobb szerzzo eseten a kapcsolattartáshoz mindenképpen kérjük megadni

2. Az összefoglalót magyar és angol nyelven kériük elkésziteni, és a cikk

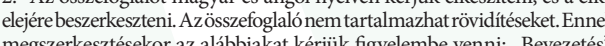

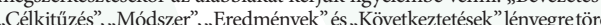

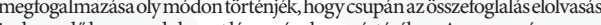
iselegendolegyena adolgozatlényegénekm megértéséhez. A magyarés azange Azösszefoglalókatkövetóón akulcsszavakat kériükszerepeltetni. Maximu öt kulcsszó adható meg magyar és angol nyelven egyaránt, szerepeljenek
továbbáa aJEL-kódok is (https://www.aeaweb.orgy/conlitifilCodes.php)!

3. A kézirat világos, jól tagolt szerkesttése különösen fontos, beleértve az

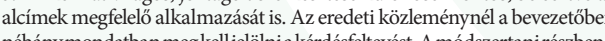
szerzóvilágosanés pontosan mutassabeéshivatkozzon azokraamódszereker amelyekalapján azeredményeket megkapta! Azeredményekés adiszkusszio

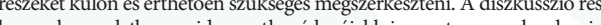

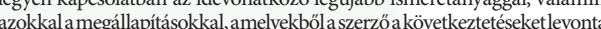
Az eredmények uijzzerúsége, illetve a szerzoỏ saját tudományos hozzáadot értekevevilagosanantanjon kiazirasbol A modszerek, eredmenyek, megbeszélés arab számokkal jelöln. Acikken belüllehetóśseg szer rintcsaka akkorlegyen alfejezeteken belüliszámozás

4. A táblázatokat címmel kell ellátni, és minden táblázatot külön lapon szükséges megadni. A táblízat ne legyen kép, a táblázatokat Wordben/
5. Az abrak a keziratban megfelelö helyen, számozottan (arab számok)

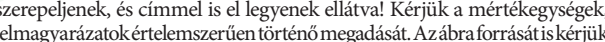

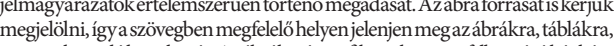
jegyzetekrevalohivatkozass.Azabrakakatesgranikonokatnagyelebontásúképkén

6. Azábrákés táblák elnevezése azábra, illetve táblízat felett szerepeljen, a

. Aképleteketképletszerkesztốvelkériükelkésziteni,ésazokatajobboldalon,

- A lábjegyzetek a felhasznált trodalom elé, a folyószöveg után kerilijenoks 9. Az irodalomiegyzék felsorolíśánál ne legyen számozás vagy bármilyen

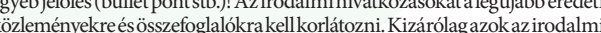
felsorolások sorolhatók fel, amelyekrea szövegben utalástörtént, ésközvetlen kapcsolatban vannak a kutatott problemaval. Ha

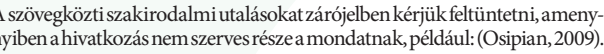
Amennyiben valamelyik szerzotot tobb, azonos éven megelent munkára b, c stb. indexet! Szó szerinti idézetnnél az oldalszám kötelezóén jelölendố. Az irodalomjegyzeketet a tanulmanny végén ábécésorrendben közöljék a - Könyveknél:

Dickson DCM (2005): Insurance Riskand Ruin, Cambridge University Press - Tanulmánykötotetetekben, gyüijteményeskeötetekben megjelent publikáaiEfficiencyof ofan Insurance Provider-AMeasurement Error Approach" "CESifo Working Paper Series 928 , CESifo Group, Munich

- Folyóiratban megielent cikkeknél: Wiltrud Weidner - Robert Weidner (2014): Identifikation neuer Ansaitze
zur individuellen Kfz-Tarifierung, Zeitschrift fur die gesamte Versicherungswissenschaft
May, Volume 103, Issue 2.pp. 167-193.

(2006) Premiums and reserves for life insurance products. Australian Actuarial Journal, vol. 12 (2), pp. 259-279.

(2) How insurace works

Online: http://www insuranceeuropeew/uploads/Modules/Publications/ how-insurance-works.pdf

10.ét-háromoldalanłkéntkérünkjijvasolniegy-egykiemelésrescántmondatot mondatrészt a szövegböl.

1. A BiztositásésKockázat folyóratcsatlakozotta DOICrossRefrendszerher,

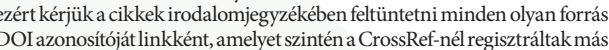

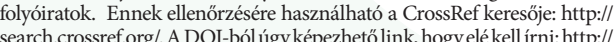
x.doi.org/

12. Aszerkesztöség szivesen fogad recenziókatis,melyekegybiztositásszakmai sempontbolerdekesnek

- Szzïkséges feltén

- Tartalmazniakell minimálisanakönyvszakszerüismertetését,sszerkezeti lẹ̈pitesest. A recenzió szerzője ezen túlmenően megosztjia az olvasóval a

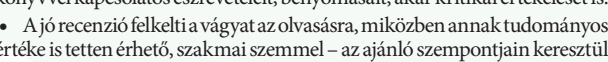
- orientálja a könyv potenciális olvasóját. - Azidézetetéśfforrások megjelolóséénél- amennyiben ilyenek vannak-be - Ajánlott teriedelem: 2-5old

Köszzonjü̈k, hogya megfelelöen elókészitettkézirattalön is segitit munkánkat. Biztositásés Kockázat Szerkesztősége 